\title{
BUILDING COMIC IMAGINATION THROUGH POLITICAL PARODY: A CRITICAL DISCOURSE ANALYSIS ON DONALD TRUMP IN THE PRESIDENT SHOW AND SATURDAY NIGHT LIVE'S THE PRESIDENTIAL DEBATE
}

\author{
Isna Ardyani Fataya \\ Interactive English Language Center (IELC Solo) \\ e-mail: isna.ardyani@gmail.com
}

\section{ABSTRACT}

The number of Americans watching political comedy shows has significantly growing recent years. The views increase as TV channels spread their programs into social media, such as YouTube. The comic and funny aspects depicted in the political parody can be in the forms of imitation, impersonation, and reflection of one's character, expression, and appearance. This paper aims to investigate American TV programs, The President Show and Saturday Night Live's The Presidential Debate, by employing humor theory seen from Van Dijk's critical discourse analysis. The dialogues used by the impersonators are analyzed to figure out the elements of funny features, comedy, and parody. Hence, the purpose of this study is to answer whether or not the discourse mechanism can build humor in The President Show and Saturday Night Live's The Presidential Debate. The data apply ten Comedy Central's YouTube videos and four Saturday Night Live's YouTube videos. The data comprises of political and power discourse. The analysis concludes that both shows utilize some aggressive strategies to criticize Trump's character, such as metaphor to represent policies, contrast to illustrate positive self-representation, and hyperbole to demonstrate racism. While Saturday Night Live applies Hillary Clinton to contrast Trump's image. Saturday Night Live contrast Trump by applying strategies such as disclaimer, implication, incongruity, aggressive, and illustration to criticize his personalities and his controversial political decisions.
\end{abstract}

Keywords: Donald Trump; Hillary Clinton; impersonation; political parody; Saturday Night Live; The President Show

DOI $\quad:$ https://doi.org/10.22146/rubikon.v7i2.62746

Available at https://jurnal.ugm.ac.id/rubikon/article/view/62746

This work is licensed under a Creative Commons Attribution-ShareAlike 4.0 International License
Article information

Received: 13 August, 2020

Revised: 27 August, 2020

Accepted: 10 September, 2020 


\section{INTRODUCTION}

Humor can be referred to as an umbrella term to describe all forms of funny, amusing, or laughter-evoking situations such as the production of a sitcom, the performance of stand-up comedy, and the process of joketelling. Recently, humor has often been employed in political parodies to get the public's attention. The infusion of politics into entertainment and the infusion of entertainment into news have proliferated to engage public culture (Hariman, 2008, p. 248). Moreover, the rise of political talk shows featuring political parody started to gain momentum approaching the 2016 US presidential election (Esralew \& Young, 2012, p. 339). At the time, the media impersonations of political figures have become an effective device to promote some political campaigns. Rose, as quoted in Hariman (2008), argues that parody may define as "the comic functioning of preformed linguistic or artistic material." It means that the comic and funny aspect depicted in the parody can be in the form of imitation, impersonation, and reflection of the political figure's character, expression, appearance, and gesture.

According to Hariman (2008), parody defines as "the exaggerated imitation of a person to achieve a comic effect." It contains four intentional acts: the flaunting of objects, the imitation of texts, the critical acts, and the comic action meaning that these acts portray amusing style, physical character, selfdeprecation, and dismissive attitude (RossenKnill, 1998, p. 32). Specifically, the relationship between comic and political elements makes parody "more complicated than simple critique" (p. 46). Hence, due to the implicit meaning in political parodies, viewers need some background knowledge to get the jokes (Matthes and Rauchfleisc, 2013, p. 597). Rossen-Knill (2008) argues the following:

The parodic message, whether it highlights criticism or humor, cannot take an explicit form. Even the minimal parodic message must be "worked out" by an audience, with the understanding that the speaker expects her audiences to work it out (p. 46).

Based on these insights, it can conclude that parody may speak to different audiences in different ways. If the viewers succeed to understand the message, they will figure out the comic element intentionally transported by the parodist to the viewers. On the contrary, if they fail, they might respond with a simple sense of amusement due to the silliness of the parodic acts (Matthes \& Rauchfleisc, 2013, p. 604).

In current times, there have been numerous trends of bringing political parody into talk shows. Sultan et al. (2019) argue:

Talk shows are most prominent among other shows as they are precise and present bitter facts in a very light way by commenting, satirizing, analyzing and criticizing in much funny style.

It conveys some news by exploring specific words, accents, tones, indirect speeches, or other similes and metaphors used by the impersonators. It airs on the television program emphasizing humorous coverage of current issues and parodies of political figures. In other words, a political talk show has become both an intriguing program for the public and a platform for the politician to administer power and dominance over society. Besides, some talk shows enrich viewers with recent American issues and influence them. Kucera, (as quoted in Sanchez, 2016) points out:

Last year, late-night shows and political communications had walked closely towards political discourse, showing that 
the combination of political issues and humor has begun to have a real influence on the public's political knowledge and opinions (p. 6). Humor can serve as a powerful rhetorical tool when employed by political officials. For that reason, political discourse persuades and convinces different rhetorical styles, such as personalization, nominalization, irony. Consequently, this tendency is leading to the dramatization of politics (p. 18).

As the era of technological advancement skyrocketed, late-night comedy shows have moved forward to streaming platforms and social media such as YouTube, Facebook, Instagram, and Twitter. The consumption of this genre unexpectedly raised by 50\% in 2016 (Zoglin, 2016). This trend leads to viral momentum in political content, which mostly affects some political figures. Specifically, the viral phenomenon had an important effect during the 2016 US presidential election campaign between Donald Trump and Hillary Clinton (Brewer \& Gao, 2008). Some latenight shows even reach high rating programs for provoking political campaigns to the viewers. Despite somewhat simplistic, presenting political issues in aparticular manner can lead viewers to think that politics is enjoyable, thereby stimulating political participation (p. 92). From this perspective, the combination of political issues and humor began to have a real persuasive influence on the public's political knowledge and opinion (Kucera, 2015). It the end, this strategy is benefited by certain figures as the medium to pursue their political propaganda.

Politics, despite its formality and seriousmindedness, is still inseparable from humor and comicality. In this context, people who follow the political events of a nation might turn politics into something comical for the mass. Some preferred methods in obtaining comicality from politics are through stand-up comedy, late-night television, and impersonation of political figures (Hakola, 2017). The phenomenon of turning the political figure into a comical show for the mass also commonly occurs in the United States. Some well-known figures are indisputably impersonated by talk shows' impersonators to demonstrate amusing aspects making viewers laugh as the depictions of negative stereotypes, shortcoming, fatal flaw, and personal character. Further, the former presidents, the current president, and the presidential candidate of the United States also have become the objects of political impersonations in the television programs and YouTube channels such as Bill Clinton, Hillary Clinton, and Donald Trump. Several late-night shows such as The Tonight Show, The Saturday Night Live, The Rosie O'Donnell Show, and The Late Show with David Letterman feature politicians as a prominent target of joke and impersonation (Matthes \& Rauchfleisch, 2013; Becker, 2018; Hariman, 2008). The programs provide politicians with "a comic stage and an outlet for successful self-mockery and ridicule" (Becker, 2018, p. 794). As Gray, et al. argues:

Since its earliest days, Saturday Night Live has inserted itself into the political arena, mocking the politicians of the day - from Chevy Chase's caricatures of a clumsy Gerald Ford to Dan Akroyd's version of a grumpy Richard Nixon, to Dana Carvey's parody of George Bush's "thousand points of light" speech, to debate parodies during the 2000 election starring Will Ferrell as George W. Bush and Darrell Hammond as Al Gore (as quoted in Becker, 2018, p. 793-794).

The growth of political impersonations as part of humor has attracted researchers' interest in analyzing such a topic. There are 
several previous kinds of research analyzing political humor in the United States from myriad disciplines. Compton (2016) takes a popular show in the United States titled Saturday Night Live. He explores the responses given by the presidents of the United States, such as Gerald Ford, Bill Clinton, and George W. Bush, toward their impersonations in Saturday Night Live. His findings mark that some presidents can find the amusements from the mockeries targeted to them. Instead of feeling dejected, they laugh along with the mockeries and reply to the mockeries with other jokes (Compton, 2016). Another research is conducted by Sanchez (2016), who investigates the 2016 US presidential candidates, Hillary Clinton, and Donald Trump's interviews on the late-night comedy shows. The study aims to analyze the type of language, the rhetorical used, and the kind of viral elements found in their performance. The finding reveals that political discourses are mainly used by the impersonators when they are impersonating public figures and representative authorities of society while personalization humanizes the audiences.

Still, in the same medium of research, Hakola (2017) observes the contents of Saturday Night Live containing the topic of the presidential election. The selected objects of this research are the impersonations of Hillary Clinton and Donald Trump when they were presidential candidates. The findings reveal that based on the contents, Saturday Night Live employs different aspects of impersonating Trump and Clinton. Trump's impersonators directly attack his physical characteristics and personality. Meanwhile, Clinton's impersonators focus on her political decisions. Similar to Compton's and Hakola's research, Becker (2018) also explores the political humor on Saturday Night Live and Donald Trump. However, different from Hakola's research, Becker (2018) analyzes people's perceptions toward Trump when he shares his response regarding his impersonations via Twitter. The results of her research revealed that Saturday Night Live makes Trump gain positive response from netizens since they find Trump's impersonations in Saturday Night Live are biased and lack of amusement (Becker, 2018). From the previous researches, late-night talk shows, such as Saturday Night Live, become a favored medium to analyze political impersonations of US prominent figures. Hence, this researches attempts to look at another late-night show demonstrating Trump's impersonation over his characterbased, personal failing, self-deprecation, and dominant power toward himself as the president. This research also looks at SNL's presidential debate. However, this analysis further explores the significance of the impersonations of Hillary Clinton in the presidential debate and another popular Donald Trump show that is The President Show.

In discussing humor in the political parody, talk show functions as an act that enables social actors to use humor for serious purposes. It becomes a communicative way to raise social issues regarding something important, reliable and significant, i.e., the struggles of the working class depicted by Charlie Chaplin to conform social codes and behavioral standards have invoked a humorous discursive mode of the severe suffering undergone by many working class in the era (Deveau, 2012, p. 36). The exposure of political comedy shows can enhance audiences' understanding of political issues and become an effective platform to lead viewers to perceive politics as less 
complicated than it is. Thereby, political parody successfully attracts public attention and reach higher voting to the political agenda.

This research purposes of investigating an American comedy TV, The President Show, by employing humor theory from the perspective of critical discourse analysis. It analyzes the elements of dialogs used by the actors who impersonate Donald Trump, which is considered funny, intriguing, and provoking. This study aims to answer the question of whether or not the discourse mechanism builds The President Show. It utilizes qualitative research to present the analysis emphasizing the researcher's interpretation of the data (Cresswell, 2009, p. 175). The data source is ten YouTube videos from Comedy Central's The President Show and four YouTube videos from Saturday Night Live's Presidential Debate. Ten videos from Comedy Central are selected as they explore Donald Trump's personality more than other programs. In contrast, videos from SNL's Presidential Debate are chosen because they use another character which is Hillary Clinton, to expose Trump's personality. After investigating the data, Trump's impersonation is compared to Hillary Clinton's impersonation in the $S N L$ to figure out the dissimilarity of humor strategy employed by the impersonators.

This research applies a critical discourse analysis approach to find out how social power, dominance, and inequality are enacted, reproduced, and resisted by text in a social and political context (Van Dijk, 1985; Van Dijk, as quoted in Schiffrin, 2001, p. 352). It gives insights into the connection between the use of language and the exercise of power and ideology (Fairclough, 1995, p. 23), i.e., how the language used by the impersonator shows Trump's character and dominant power as the
US president such as by uttering repeated use of words: huge, unbelievable, fantastic and genius to indicate power, populist leader and aggressive look (Hakola, 2017). Besides, the way Atamanuik, as the impersonator, utilizes facial expression, gesture, body position, and language to impersonate Trump's domination, power, including superiority, make the show even more appealing. The analysis of the expressive meaning of words and modes of speaking look at the persuasive strategies to inform American social issues.

According to Van Djik (2004), power is not only a way to control the acts of other people, but it also controls the minds as the basis of action, which is discursive (p. 25). Media power, such as television, is generally symbolic and persuasive in the sense that it can control the minds of the viewers, but not directly their action. Humor emerges as a powerful tool when employed by political figures. In this line, Van Dijk (1998) brings discursive concepts linked to the use of language and ideology to reveal positive selfrepresentation toward certain people supporting internal group and negative otherrepresentation toward others (p. 69).In this case, CDA analyses the discourse to find the hidden meaning and to reveal that political discourse creates the power to certain dominated group.

The President Show is an American comedy television that began its premiere on Apr 27, 2017, on Comedy Central TV Channel, owned by Viacom Global Entertainment Group (Szalai, 2012). Anthony Atamanuik hosts the show as Donald Trump collaborated with Peter Grosz as US Vice President, Mike Pence. Atamanuik began impersonating Trump during the 2016 United States presidential campaign. Previously, he 
also appeared on several talk shows during the campaign, including @midnight, The Chris Gethard Show, and The View (Sanchez, 2017). In contrast, Saturday Night Live is an American late-night television sketch comedy created by Lorne Michaels. Both the programs revolve around political jokes and social issues such as American-Mexican borders, Republican versus Democratic Party, US tax, environment policy, and global warming.

\section{DISCUSSION}

After analyzing ten videos that impersonate Trump as US president, the findings figure out that there are political discourses and power discourses that are visible throughout the shows. From the political discourse, The President Show applies some strategies, i.e., metaphor strategy is utilized by Atamanuik to illustrate Trump's policies, contrast strategy to produce positive self-representation, and hyperbole strategy to demonstrate racism. In the power discourse, several discourses strategies bring audiences to realize the hidden meaning of comic aspects within the show, such as implication, incongruity, aggression, and illustration.

\section{Political Discourse in The President Show}

In this show, Antony Atamanuik impersonates Trump's verbal utterance and body language. Even though this show mostly makes fun of Donald Trump and falls within the comic genre, the scripts contain political discourse related to American political issues. Based on Martin's and Ford's theory of humor (2018), the type of humor which frequently occurs in The President Show is aggressive humor. The selected videos represent Trump as a person who possesses a high level of selfconfidence and has positive views toward people who support his policies. As for people who disagree with his policies, the impersonator represents Trump as a person who is unnegotiable and unfeasible to understand. According to Martin and Ford (2018), aggressive humor intends to be a means for criticizing others in the form of insult. The impersonator uses it as a tool for criticizing Trump's mannerisms and the political decisions he has made during his reign.

Van Dijk's (2000) strategies analyze the aggressive humor in the videos, which are metaphor, contrast, and hyperbole. According to Van Dijk (1997), political discourse studies revolve around professional politicians such as president and prime ministers. Most of the scripts are based on what the President of the United States delivers or writes on the media. From Van Dijk's strategies (2000), the humor in The President Show consists of political contexts.

\section{Metaphor Strategy as the Presentation of Policies}

Van Dijk's first strategy found in this show is a metaphor related to Trump's policies. The excerpt of the script is as follows:

Trump: "It's great to be back in America. How very much I've loved you, how very much I've tried my best to give you a good life. It's hot in here, or did I pull out of the Paris Accord. Nothing good. What a terrible deal that was for America everyone says, "Trump. Trump. What about the melting ice caps?" Don't worry.My environmental policy will take care of the Penguins. The Pittsburgh Penguins. A tremendous hockey team. The bird penguins can get incredible 
jobs as coal miners." (Comedy

Central, 2017, 00:18)

The context of this humor refers to Trump's decision to withdraw the United States from the Paris Agreement on climate change. The impersonator uses the metaphor 'the melting ice cups' to refer to 'global warming.' This kind of text belongs to Van Dijk's metaphor strategy in which the impersonator of Trump represents Trump's image when he declares disbelief toward climate change (2000). Since Trump regards climate change as unreal, the impersonator uses the metaphor 'the melting ice cups', referring to melting ice in North and South Poles due to global warming. The metaphor shows the disinterest of Trump regarding climate change. Melting ice in the North and South Poles is as unimportant as melting ice cups. The life of real penguins is less necessary than Pittsburgh Penguins, or colloquially known as the Pens, an epithet emanated from a professional hockey team based in Pittsburgh, Pennsylvania. Hence, the impersonator criticizes Trump's derogatory view toward climate change, which is, in fact, very crucial.

By analyzing the example above, metaphor in the political context function as a tool to attack political opponents, the presentation of policies, or the legitimation of political power. In this case, Trump's impersonator points out the way Trump acts toward people who are in a disagreement with him on the debate over climate change. The term 'melting ice cups' is the metaphor of global warming, and at the same time, it becomes the presentation of environmental policy in the United States. The metaphor of global warming as the melting ice cups functions as a hint to the audience for what political context the impersonator wants to deliver. Trump declares, "The Paris Accord would undermine our economy, hamstring our workers, weaken our sovereignty, impose unacceptable legal risks and put us at a permanent disadvantage to the other countries of the world." (as quoted in Chemnick \& Sobczyk, 2019). The metaphor in the script considers Trump's confirmation on the global warming issue, which is different from his statement that he disregards Paris can impose the administration.

\section{Contrast Strategy as the Medium to Positive Self-Representation}

Van Dijk's second strategy (2000) is the contrast strategy. According to him, this strategy functions to emphasize someone's positive quality by comparing it to others. The following script shows the contrast strategy between Trump and a climate scientist. The political context is still related to global warming. The excerpt of the script is as follows:

Interviewer: "But all the scientific studies indicated...."

Trump: "Oh, who cares about science? That's Bernhardt's. I'm fighting for the forgotten man. He doesn't read studies. He's the man who forgot to read."(Comedy Central, 2017, 01:01)

The scene indicates that Trump disbelieves science and evidence of global warming. The impersonator employs the contrast strategy used to emphasize the positive quality of Trump by comparing it tothe said climate scientist. This scene is under the news in which Trump accused scientists of having a political agenda by using climate change as their tool and also considered that climate change as a hoax (Blumberg, 2018). The name Bernhardt in this scene might refer to Trump's interior chief, David Bernhardt. He is leading the environmental groups in Trump's Cabinet. 
However, his political strategies in the cabinet do gain unpleasant remarks from the media.

Politically, the contrast strategy emphasizes the polarization between self and other (Entman as quoted in Van Dijk, 1997). By looking at this scene, it is clear that the impersonator tries to depict Trump's positive representation by letting down his chief's name. People can formulate hypotheses about self, and others, which represent the self-group in more positive ways than the other group (Van Dijk, 1997). In this scene, the impersonator points out the difference between how Trump sees himself and how Trump sees other people. The impersonator's acting depicts Trump as a person who has positive selfrepresentation toward himself but does the opposite when it comes to others.

\section{Hyperbole Strategy as the Medium to Demonstrate Racism}

The following scene is regarding the issue of immigrants, and the impersonator uses the hyperbole strategy to play his role as Trump:

Interviewer: "Why does your immigration plan place so much importance on the ability to speak English?"

Trump: "If you want to live here, you need to talk English very well. As a president who English great, I know job good is important for a job done. My stand with good Americans like local milk people. So true. So true." (Comedy Central, 2017, 00:41)

In this scene, it seems that Trump is making fun of immigrants who are not fluent in English by imitating how they speak in broken English. Hyperbole strategy is commonly used by political speakers when they are elaborating on their groups and other's groups (Van Dijk, 2019). The other group, in this case, is the immigrants who come to the United States without having proficiency in English skills. The impersonator is exaggerating the way Trump impersonates how the immigrants speak. Simultaneously, the impersonator also shows that Trump's ability to speak English is not as excellent as it seems. There is a website that attempts to measure the complexity of Trump's vocabularies by using a common metric, the Flesch-Kincaid Grade Level. The results show that Trump's vocabulary and grammatical structure ranks the last compared to the former presidents of the United States, and his speaking ability is equivalent to a fourth-grade level. As stated on the website:

By every metric and methodology tested, Donald Trump's vocabulary and grammatical structure are significantly more simple, and less diverse, than any President since Herbert Hoover, when measuring "off-script" words, that is, words far less likely to have been written in advance for the speaker (Firschling, 2018).

Firschling (2018) reaffirms Trump's language use of English is, in fact, less qualified than the previous US president. Trump's statement seems to exaggerate the condition in which he compels immigrants to master English with a proper grammatical rule before transporting to America. He forgets that America is a multicultural country where many immigrants come there without mastering English fluently. Thus, his speaking tends to underestimate the majority of immigrants who unable to speak English well.

\section{Comical Points in Political Discourse}

After taking a glimpse of the examples above, it can conclude that aggressive humor dominates the show consisting of teasing and 
insulting a person. In The President Show, even though the impersonator acts like Donald Trump, what the impersonator does is mocking Trump in several ways. Warren and McGraw (2015) propose an idea that people laugh as they perceive the situation as playful, amusing, acceptable, or benign. The audience regards the show in the playful context where they know what the impersonator says about the president is merely a joke. In this case, the displays of disrespectful behavior toward Trump is a violation of moral norms. In some scenes, the impersonator teases Trump's habits and political decisions upon US policies in his administration. However, it is benign in some way because the audience enjoys the show alongside his/her family or friends. It would turn out to be unfunny if they sat and watched The President Show with the actual Trump by their side. The situation indeed would be threatening and would lose its comicality. Thus, the context and situation make something funny.

There are several scenes in The President Show which apply aggressive humor as a means to criticize Trump. The ways these aggressive jokes are through different strategies such as metaphor, contrast, and hyperbole to disclose Trump's character and personality in offending such derogatory statements toward others. Since Van Dijk's strategies focus on positive self-representation and negative other-representation, it sees from the jokes that real-life Trump has positive selfrepresentation. As for the outer groups who do not in agree with him, the impersonator shows him as a person who sticks to his guns - in a negative way. The aggressive humor also reveals the injustice treatment carried out by Trump toward the outer group, prompting some contentions with his policy. Sanchez (2017) argues, “In current times, Trump's language is dominantly aggressive and negative when he refers to the 'others.' The way he answers is always with short phrases and political content. However, he fills the discourse with emotions and rhetorical tools to show his personality dealing with others". Thereby, Atamanuik in The President Show comprehensively impersonates Trump by uttering language as a rhetorical tool to indicate his strength as a stiff and a powerful president. Furthermore, some derogatory words emerge as an insult, euphemism act as an indirect word to refer to something embarrassing or unpleasant, "sometimes to make it seem more acceptable than what it is" (Hornby, 2004, p. 339-428).

\section{Power Discourse in Saturday Night Live}

According to Van Dijk (2001), political discourse represents the enactment, reproduction, and the legitimization of power and domination. Power discourse is also employed in the political impersonation on Saturday Night Live during the 2016 US presidential election. Here, Hillary Clinton was impersonated by Kate McKinnon in her character as an entertaining, easy-going, and ambitious woman (Hakola, 2007, p. 5). She debates her competitor, Donald Trump, impersonated, by Alec Baldwin. In the first section of the debate, the impersonator uses other-directed hostile to attack Trump by emphasizing negative opinions such as failure and disaster. Other-directed hostile humor functions when "the comedian acts as the satirist, presenting a hostilecritique of a politician" (Becker, 2012, p. 792). The theory argues that seeing people from their body language, characters, accent, expression, choice of words, and weakness could find jokes that result in something funny. 


\section{Implication Strategy as Personal Discourse}

The Saturday Night Live depicts Hillary Clinton as a woman having the capability to control her mind and behavior as a politician to solve the social problem.

Clinton: "Listen, America. Donald Trump cannot be president. He would be a disaster. A failure. A complete "f." And America, you deserve better than an "f." So on Nov 8, vote for me, and I promise I will be a stone-cold "b." (The Saturday Night Live, 2017, 09:08).

The statement above represents the power discourse of Hillary. She shows that if she wins the election, she will give her best. Van Dijk (2001) argues that power can control the social power of someone. In Hillary's speech on Saturday Night Live, she shows her power as the presidential candidate. However, her power is different from Donald Trump since she is controlling her minds in the way she talks during her speech compared to Donald Trump, who tends to show off his power. In this dialog, the impersonator utilizes personal discourse to construct Clinton's image and mark strong motivation. The choice of personal discourse can identify the discourse markers that the speaker intends to convey. Alavidze (2017) insists that the choice of deictic words such as personal pronouns is the weapon used by politicians to achieve their goals. Karapetjana (2011) suggests that the pronoun 'I' implies a personal level to show authority and personal responsibility as well as commitment and involvement (p. 43). 'I' evokes the speaker a personal voice that distances her from others. "This means that it cannotexpect that the other members of her party agree with the speaker's opinion when the pronoun 'I' is employed."
Besides, the individual speaker attempt to express her principle, morals, power, and someone who is not afraid to take action when necessary (Bramley, 2001, p. 28). As he argues:

Doing "being a good politician" involves showing oneself in a positive light. The use of ' $I$ ' in conjunction with talking about what the interviewee is doing to be a good politician. Self is also represented as an individual when the politician expresses opinions about and responds to situations, gives descriptions or narratives about oneself, recounts actions that the politician has performed with his/her job as a politician, shows his/her authority, knowledge or responsibility towards certain issues (Bramley, 2011, p. 37).

Bramley's argument concludes that pronoun in political discourse represents the speaker as a good politician by showing her promise, reputation, and commitment to choose as a candidate.

\section{Incongruity as Political Discourse}

Host: "That was incredibly rude to secretary Clinton."

Clinton: "Thank you, Chris. That's exactly the kind of language that has poisoned and debased this election. and if you agree, go to hillaryclinton.com and buy a limited edition nasty woman mug.com (The Saturday Night Live, 2017, 07:04)

In Clinton's statement above, it shows that previously the host asked some raising taxes to save the programs like social security that will be executed by her. Then, Clinton tries to explain what kinds of social security and Medicare previously mentioned. She confirms that she takes her responsibility to contribute to social security and Medicare. Trump responds by saying Clinton is anasty woman 
considered rude and offensive statement during the political debate. As a masculine leader, he tends to deploy his strength to mock others by bullying and offending vulgar utterances. In the end, Clinton normally responds to him by promoting her website on hillaryclinton.com and selling her mug through an online shop.

Clinton deliberately gives the unreliable and unrelated answer to drive the host move to another question and forget to fulfill the previous question. Here, incongruity comedy tends to give some missing information that might become useful information to the viewers expecting a significant answer. The effect of incongruity is that somehow viewers end up with a disappointing feeling as the answer do not fulfill their expectation. Based on Van Dijk (2000), he argues that incongruity has a meaning of giving incomplete explanation to the recipients. It implies that the strategy happening here is the unsatisfying comment given by Clinton. When the host supports her as Trump ridicules Clinton by saying 'a nasty woman,' the impersonator promotes her product by asking audiences to visit certain websites and buying a mug instead of giving a relevant answer.

Besides, during this scene, several singing moments on the show effectively utilize incongruity in comedy in which humor arises from the unexpectedness of a singing politician. It implies that Clinton could control her trait, which is different from Trump's impersonation. Hakola (2017) argues that Clinton wrote an article in a 'human of New York blog' telling that women must control her emotion when she wants to make a career in a man's world. Therefore, Clinton's impersonation in Saturday Night Live reveals that she turns up to be an ambitious woman controlling her emotion while arguing her opinion. The incongruity also occurs in the following scene:

Host: Wikileaks has been releasing your campaign e-mails, many of which raise some serious questions.

Clinton: Thank you for bringing up my e-mails, Chris. And I am very happy to clarify what was in some of them. Sorry, what, Carol? What? I'm sorry, I thought I heard my friend Carol (The Saturday Night Live, 2017, 04:04).

The dialogues uttered by the impersonator reveal that she prefers to throw out the question by giving irrelevant answers. Based on Van Dijk's theory, the dialog above belongs to the incongruity strategy. When the host asked her to clarify some emails containing political campaigns, she disrupts it as if she listened to the voice of her friend, Carol, who called her name. These implications strategies create a shock to laughter as the impersonator gives an unrelated answer.

\section{Illustration Strategy as Power Discourse}

\section{Clinton: 'I don't know if you've heard} this before. But I was instrumental in taking down a man by the name of Osama bin Laden (The Saturday Night Live, 2017, 05:48)

Clinton tries to reveal her statement after hearing Trump's utterances of answering the host's question of the economy that he is better equipped than Clinton. She also provokes a statement regarding the economic system that it arrives at a serious problem. She admits the problem needs much careful attention (The Saturday Night Live, 05:32-05:58). In her statement, she shows unexpected ridiculousness by acting as a singer while 
mentioning a name, Osama bin Laden referring to the Twenty Years' War between the United States and Al-Qaeda, a conflict that both sides have ultimately lost. During the administration of George W. Bush, America aimed against the Taliban regime, declaring war againstthe Middle Eastern country (Tierney, 2016). The worst risk, America spent a multitude of economic budget on its military forces in the time combating the massive attacks. In this case, the illustration strategy is used by Clinton to illustrate the name of Osama Bin Laden behind the incident Twenty Years' War towards American foreign policy. Van Dijk (2000) argues that powerful argumentation is acceptable if the illustration is provided by depicting actual information. Illustration in the power discourse functions to highlight important issues toward social problems to reveal the hidden meaning of the language uttered by the speaker.

\section{Disclaimer Strategy as Power Discourse}

In the following script, Clinton applies a disclaimer as a discursive strategy to promote herself to be a president after Trump ends up his statement. Her statements invite some persuasive way from her basis of power. This statement indicates that, due to her previous experience as a politician, she convinces the viewers that she could achieve her goals.

Clinton: "Listen, America. You hate me, my voice, and my face. Well, here's a tip. If you never want to see my face. Gain, elect me president, and I swear to god I will lock myself in the oval office and not come out for four years. But if you don't elect me, I will continue to run for president until the day I die, and I will never die" (The Saturday Night Live, 2017, 08:00).
The scene above brings the audience to the last session of debate whenClinton demands the viewers to elect her as US president. According to Van Dijk (1998), the disclaimer serves as a discursive strategy in which the speaker presentsa positive representation of self-legitimation and rejects it with a particular term such as 'but.' It functions to preserve the face of the speaker; in this case, Clinton does not expect the recipient to have a negative perception of her. Therefore, the disclaimer strategy typically serves as a positive-self representation. Additionally, it also works to "maintain the political stance by maintaining the respect to the audience and legitimize the in-group and the outgroup member" (Van Dijk, 1995). It uses to show prejudice, mitigate, or to respect the audience since they may have a different perspective of a particular case (Irfam \& Wahyudi, 2012, pp. 93-95).Based on the theory, Clinton's statement is involved in disclaimer apparent effort in which the speaker portrays the effort to show her persistent desire to be a president.

\section{Comical Points in Power Discourse}

Compared to Donald Trump's impersonator in The President Show, Hillary Clinton's impersonator in Saturday Night Live portrays more on Clinton's character as calm, direct, persistent and brave women. Through the entire dialogues, the impersonator wants to show Clinton's strength as a woman dealing with her competitor, Trump, in the presidential debate. Whereas in The President Show, the impersonator, somehow, reveal Trump's personality as uncompromising, selfexaggerating, and arrogant man. From his speeches, he tends to respect others, supporting his thought. Contrastingly, he does the opposite by disregarding people rejecting his policy. As Saturday Night Live has been 
airing since 1975, in 2016, the audience got their new refreshing on Saturday Night Live. In that year, the United States had a big year of the presidential election between Republican presidential nominee, Donald Trump, and Democratic presidential nominee, Hillary Clinton. However, Saturday Night Live shows more on how Hillary Clinton tries to defend her opinions toward Trump. Her defenses are mostly in the form of aggressive humor, which tends to create comic aspects in the midst of her speaking toward political issues.

\section{CONCLUSION}

The phenomenon of turning political figures into a comical show for the mass has commonly occurred in the United States. The former presidents and the current presidents of the United States have become the objects of political impersonation in late-night talk shows. Hillary Clinton in the Saturday Night Live and Donald Trump in The President Show are among talk shows, which ultimately impersonates US political figures. It even combines the comic over political campaign to obtain the public vote, especially in the period of the presidential election. Some late-night shows achieve high rating programs to provoke political campaigns to the viewers and boost political purposes to spread the rhetorical agenda. Hence, political talk shows involving political parody emerge as the platform to familiarize public with the infusion of humor, amusing, entertaining aspects so that viewers funnily enjoy political issues.

There are several scenarios on The President Show that use aggressive humor as the means to criticize Trump. Here, political and power discourse criticizes his personalities and political decisions, such as how he handles the issue of global warming and his viewpoint of immigrants. By analyzing the political and power discourse, the data figure out how Trump's character is criticized and utilized to depict his behavior and personality. Besides, the ways some aggressive jokes on the show are through different strategies such as metaphor, contrast, and hyperbole. Compared to Hillary Clinton impersonated by Kate McKinnon in the Saturday Night Live, some other aggressive strategies are employed to depict Clinton's character. The impersonator uses strategies such as disclaimer, implication, incongruity, and illustration strategy to depict Clinton's character as an entertaining, easygoing, and ambitious woman. In sum, it can conclude that jokes regarding stereotypical, physical traits and character flaws of political figures dominate US political parody to get the jokes, such as by commenting, satirizing, and criticizing ironical fault, indiscretion, selfdeprecation toward other people.

\section{REFERENCES}

Alavidze, M. (2017). "The Use of Pronouns in Political Discourse." International Journal of Arts \& Sciences, 9(4), 349-356. Retrieved from http://www.universitypublications.net

Bayram, F. (2010). "Ideology and Political Discourse: A Critical Discourse Analysis of Erdogan's Political Speech." Arecls, 7, 23-40. Retrieved from https://pdfs.semanticscholar.org

Becker, A. B. (2012). "Comedy Types and Political Campaigns: The Differential Influence of Other-Directed Hostile Humor and Self-Ridicule on Candidate Evaluations." Mass Communication and Society, 15(6), 791-812. DOI: 10.1080/15205436.2011.628431

Becker, A. B. (2018). "Live From New York, It's Trump On Twitter! The Effect of Engaging with Saturday Night Live on Perceptions of Authenticity and the 
Salience of Trait Ratings." International Journal of Communication, 12, 17361757. Retrieved from: https://pdfs.semanticscholar.org/b6d5/426 3f1d3989df18e0d36c6a26b3a8ac82cee.pd $\mathrm{f}$

Blumberg, A. (2018). "Trump on Climate Change Report: 'I don't believe it."' HuffPost. Retrieved from https://www.huffpost.com/entry/donaldtrump-climatechange_n_5bfc516be4b0eb6d93128997

Bramley, N. R. (2001). Pronouns of Politics: The Use of Pronouns in the Construction of 'Self' and 'Other' in Political Interviews (doctoral dissertation). Australian National University, Australia. Retrieved from http://citeseerx.ist.psu.edu/viewdoc/downl oad?doi=10.1.1.125.4780\&rep=rep1\&type $=$ pdf

Cao, X., \& Brewer, P. R. (2008). "Political Comedy Shows and Public Participation in Politics." International Journal of Public Opinion Research, 20(1), 90-99. DOI. 10. 1093/ijpor/edm030.

Chemnick, J., \& Sobczyk, N. (2019). US Moves Closer to Withdrawing from Paris Climate Pact. Retrieved from: https://www.sciencemag.org/news/2019/1 1/us-moves-closer-withdrawing-parisclimate-pact

Comedy Central (Producer). (2017, Aug 4). There's No Chaos [Video File]. Retrieved from https://www.youtube.com/watch?v=3LcO 4UuTcPE

Comedy Central (Producer). (2017, Jun 2). Screw Science! Bye-bye, Paris! [Video File]. Retrieved from: https://www.youtube.com/watch?v=ofR5F XtAIQQ

Compton, J. (2016). "Live from DC: Saturday Night Live Political Parody References in Presidential Rhetoric." Comedy Studies,
7(1), 62-78. DOI: 10.1080/2040610X.2016.1139808.

Creswell, J. (2009). Research Design: Qualitative, Quantitative, and Mixed Methods Approach. Los Angeles: SAGE Publication.

Davis, J. L., Love, T. P., \& Killen, G. (2018). "Seriously Funny: The Political Work of Humor on Social Media." New Media \& Society, 20(10), 3898-3916. Retrieved from https://doi.org/10.1177/146144481876260 2

Deveau, D. J. (2012). English Canadian Stand-Up Comedy as a Field of Cultural Production (doctoral dissertation). Simon Fraser University, Canada. Retrieved from https://core.ac.uk/download/pdf/56376645 .pdf

Esralew, S., \& Young, G. (2012). "The Influence of Parodies on Mental Models: Exploring the Tina Fey-Sarah Palin Phenomenon." Communication Quarterly, 60(3), 338-352. DOI: $10.1080 / 01463373.2012 .688791$.

Fairclough, N. (1995). Critical Discourse Analysis. London: Longman.

Frischling, B. (2018). "Stable Genius"- Let's Go to the Data. Retrieved from https://blog.factba.se/2018/01/08/stablegenius-lets-go-to-the-data/

Hakola, O. J. (2017). "Political Impersonations on Saturday Night Live during The 2016 US Presidential Election." European Journal of American Studies, 12(2), 1-20. DOI: 10.4000/ejas.12153.

Hariman, R. (2008). "Political Parody and Public Culture." Quarterly Journal Speech, 94(3), 247-272. DOI: $10.1080 / 00335630802210369$.

Hornby, A.S. (2004). Oxford Advanced Learner's Dictionary. London: Oxford University Press.

Irham \& Wahyudi. (2012). "Treating Disclaimer as a Power Strategy of Self- 
Legitimation and Other De-Legitimation in Netanyahu's Unga Speech." Language Discourse \& Society, 2(1), 89-106. Retrieved from https://www.academia.edu

Karapetjana, I. (2011). "Pronominal Choice in Political Interviews." Baltic Journal of English Language, Literature and Culture, 1, 36-45. Retrieved from https://www.lu.lv/fileadmin/user_upload/l u_portal/apgads/PDF/BJ-Eng-

Laguage_Literature_Culture-1.pdf

Kucera, E. (2015). Late-Night Comedy and Its Effect on the Public's Political Opinion (bachelor research). California Polytechnic State University, United States. Retrieved from http://digitalcommons.calpoly.edu

Martin, R. A., \& Ford, T. E. (2018). The Psychology of Humor: An Integrative Approach $2^{\text {nd }}$ ed. Boston: D. Reidel Publishing.

Matthes, J., \& Rauchfleisc, A. (2013). "The Swiss 'Tina Fey Effect': The Content of Late-Night Political Humor and the Negative Effects of Political Parody on the Evaluation of Politicians." Communication Quarterly, 61(5), 596614.

DOI:

$10.1080 / 01463373.2013 .822405$.

Riggio, R. E. (2015). The Four Styles of Humor. Retrieved from https://www.psychologytoday.com/us/blo g/cutting-edge-leadership/201504/the-4styles-humor

Sanchez, F. (2016). Political Communication and Virality in the US Presidential Campaign a CDA Analysis of the 2016 US Presidential Candidates' Discourses and Performances in Late-Night Shows (master's thesis). Jonkoping University, Sweden. Retrieved from http://www.divaportal.org/smash/get/diva2:1116821/FUL LTEXT01.pdf

Saturday Night Live (Producer). (2016, Oct 16). Donald Trump vs. Hillary Clinton Town Hall Debate Cold Open [Video
File]. Retrieved from https://www.youtube.com/watch?v=qVM W_1aZXRk

Saturday Night Live (Producer). (2016, Oct 2). Donald Trump vs. Hillary Clinton Debate Cold Open [Video File]. Retrieved from https://digg.com/video/snl-debate-hillarytrump

Saturday Night Live (Producer). (2016, Oct 23). Donald Trump vs. Hillary Clinton Third Debate Cold Open [Video File]. Retrieved from https://www.youtube.com/watch?v=kjyltrKZSY

Schiffrin, D., Tannen, D., \& Hamilton, H. E. (2001). The Handbook of Discourse Analysis. USA: Blackwell Publishing.

Sultan, B., Rafique, N., Tariq, R., \& Imran, M. (2019). "Critical Discourse Analysis of Pakistani TV Comedy Talk Show "Khabarnaak." American Journal of Humanities and Social Science Research, 3(2), 106-111. Retrieved from https://www.researchgate.net

Szalai, G. (2012). Viacom to launch Comedy Central Extra in Adriatic Region. Retrieved from https://www.hollywoodreporter.com/news /viacom-comedy-central-extra-launchadriatic-357169

Tierney, D. (2016, Aug 23). "The Twenty Years' War." The Atlantic. Retrieved from https://www.theatlantic.com/international/ archive/2016/08/twenty-yearswar/496736/

Van Dijk, T. A. (1997). "What is Political Discourse Analysis?" Belgian Journal of Linguistics, 11(1), 11-52. Retrieved from: http://discourses.org/OldArticles/What $\% 2$ 0is\%20Political\%20Discourse\%20Analysi s.pdf

Van Dijk, T. A. (1998). Ideology: A Multidisciplinary Approach. SAGE Publications. London. Retrieved from http://www.discourses.org/OldBooks/Teu 
n\%20A\%20van\%20Dijk\%20-

$\% 20$ Ideology.pdf

Van Dijk, TA (1985). Introduction: Discourse Analysis as a New Cross-Discipline. USA: Academic Press, Inc.

Van Dijk, TA (1995). "Discourse Analysis as Ideology Analysis." In C. Schaffner \& A. Wenden (Eds). Language and Peace, 1733. Aldershot: Dartmouth Publishing.

Van Dijk, TA (2000). Ideology and Discourse: A Multidisciplinary Introduction. Unpublished manuscript, Pompeu Fabra University, Barcelona. Retrieved from http://www.discourses.org/UnpublishedAr ticles/Ideology\%20and\%20discourse.pdf

Van Dijk, TA (2004). From Text Grammar to Critical Discourse Analysis: A Brief Academic Autobiography Version 2.0. Unpublished Manuscript, Universitat Pompeu Fabra, Barcelona. Retrieved from https://pdfs.semanticscholar.org

Warren, C., \& McGraw, A. P. (2015). "Opinion: What Makes Things Humorous." PNAS Proceedings of the National Academy of Sciences of the United States of America, 112, 7105$7106 . \quad$ Retrieved from http://dx.doi.org/10.1073/pnas.150383611 2

Zoglin, R. (2016). The News Politics of Late Night. Time, 188(12), 42-47. Retrieved from https://time.com 